\title{
Na mira dos funcionários municipais: considerações acerca das infrações de postura nos distritos suburbanos do Rio de Janeiro no início do século XX
}

\section{Cristiane Regina Miyasaka*}

Resumo: O presente artigo tem como objetivo traçar um panorama da aplicação de multas por infração de posturas no Rio de Janeiro, no início do século XX, sobretudo nos distritos suburbanos. Tal proposta tem como intenção dialogar com a historiografia que trata das reformas urbanas empreendidas na cidade nessa época, procurando compreender os mecanismos adotados pelo poder público para garantir o cumprimento da legislação municipal, bem como os conflitos oriundos dessas medidas. Nesse sentido, foram analisadas as diferenças entre as autuações realizadas nos distritos urbanos e suburbanos, as multas mais recorrentes, as estratégias empregadas pelos infratores para não pagá-las, entre outras questões.

Palavras-chave: Infração de posturas - Rio de Janeiro - Subúrbios

Abstract: The objective of this article is to provide an overview about the application of fines for law infraction in Rio de Janeiro, in the early twentieth century, especially in suburban districts. It proposes a dialogue with the historiography related to the urban reforms undertaken in city in that period, seeking to understand the mechanisms adopted by public authorities to ensure the enforcement of local legislation, as well as the conflicts that arose from those measures. Therefore, it emphasizes the differences between the enforcement of fines in urban and suburban districts, which fines were more frequent, what strategies were employed by offenders to avoid the payment of them, and so forth.

Keywords: Law Infraction - Rio de Janeiro - Suburbs

Durante a década de 1870, começou a ser esboçado o primeiro projeto de reforma urbana para a Corte. A Comissão de Melhoramentos da Cidade do Rio de Janeiro foi nomeada por Dom Pedro II em 1874. Pereira Passos estava entre os engenheiros que faziam parte dessa comissão. ${ }^{1} \mathrm{O}$ alargamento de ruas, a construção

* Bolsista Fapesp (Processo n. ${ }^{\circ}$ 2012/20580-9). Unicamp. Contato: crismiyasaka@gmail.com

1 Embora Pereira Passos seja lembrado em razão da polêmica administração da capital federal entre $1902 \mathrm{e}$ 1906, o engenheiro ocupou cargos importantes desde o final da década de 1850 . Entre 1857 e 1860, fez parte da legação brasileira em Paris, acompanhando parte das obras empreendidas na capital francesa durante a gestão de Haussmann. Ao retornar ao Brasil em 1860, trabalhou na construção de ferrovias, elaborando estudos para o prolongamento da Estrada de Ferro de Cantagalo e colaborando com o assentamento dos trilhos da segunda seção da Estrada de Ferro Dom Pedro II. Em 1870, ocupou o cargo de consultor técnico do Ministério da Agricultura e Obras Públicas. Para informações mais detalhadas sobre sua carreira, ver: BENCHIMOL, Jaime Larry. Pereira Passos: um Haussmann Tropical. A renovação urbana na cidade do Rio de Janeiro no início do século XX. Rio de Janeiro: Secretaria Municipal de Cultura, Departamento Geral de Documentação e Informação Cultural, 1992, cap. 11. 
de avenidas, de uma grande praça de mercado e de uma estação marítima para a Estrada de Ferro Dom Pedro II, além da reforma do porto, estavam entre as obras projetadas. ${ }^{2}$ Tais melhoramentos não foram levados a cabo durante o final do século XIX, porém a discussão sobre a necessidade de mudanças na infraestrutura da cidade começou a se configurar nessa época. A recorrência de surtos epidêmicos de febre amarela contribuiu para a intensificação desse debate, já que passaram a ser associados às condições de salubridade do Rio de Janeiro. Eles foram especialmente graves em 1873 e $1876 .^{3}$

Com a Abolição da Escravidão e a onda imigratória do final do século XIX, a crise habitacional enfrentada pela capital federal se agravou. Segundo o médico demografista Aureliano Portugal, o número de habitações coletivas na cidade quase quadruplicou entre 1888 e $1890 .{ }^{4}$ Dados referentes ao recenseamento de 1890 indicam que $81 \%$ da população carioca residiam nos distritos urbanos e $18 \%$ nos suburbanos. ${ }^{5} \mathrm{~A}$ despeito dessa diferença, ainda na década de 1890 começaram a aparecer pessoas interessadas em ampliar a ocupação da zona suburbana, que em diversos distritos ainda tinha um aspecto bastante rural.

Em janeiro de 1891, foi firmado um contrato entre João Luis dos Santos e o Conselho Municipal do Rio de Janeiro, que previa a construção de cinco avenidas (habitações coletivas) e a realização de "melhoramentos", como ruas e praças, nos distritos de Engenho Novo, Inhaúma e Irajá. ${ }^{6}$ Nesse mesmo ano, Prudêncio Paschoal Telles dos Reis, Ignácio Antonio Teixeira Jr. e José Baldraco apresentaram a seguinte proposta ao Ministro da Agricultura, Comércio e Obras Públicas:

[...] fundar com as duas freguesias suburbanas de Irajá e Jacarepaguá, a partir do Campinho, uma espécie de cidade, onde, em terrenos quase abandonados e de fácil aquisição, serão construídas três mil casas, não só para a habitação de operários e classes pobres, oficinas e comércio local [...].

Pretendem os suplicantes com estas edificações não só facilitar a todas as classes a obtenção, por aluguel ou compra razoável, de uma casa com as condições higiênicas e em um bairro aprazível e perto da Capital (onde atualmente se encontra com dificuldade casas para alugar, o que significa que o número destas é insuficiente para a população da cidade), como também povoar um bairro que, pelas vantagens que oferece, terá em breve grande desenvolvimento, superior, talvez, ao que já se nota em outros que não oferecem iguais vantagens. ${ }^{7}$

Como é possível notar, os interessados justificaram a construção de tais casas em razão do problema habitacional enfrentado pela cidade, especialmente grave nos distritos centrais. Vale destacar a intenção em edificar casas com "condições higiênicas" para os "operários e classes pobres". Subentende-se, a partir desse raciocínio, que aqueles que viviam nas áreas centrais da cidade não gozavam de boas condições de moradia.

2 Cf.: BENCHIMOL, Jaime. Op. cit., cap. 8.

3 Para acompanhar os debates a respeito das epidemias de febre amarela, suas formas de transmissão e suas relações com a imigração e a decadência da escravidão, ver: CHALHOUB, Sidney. Cidade febril: cortiços e epidemias na Corte imperial. São Paulo: Companhia das Letras, 1996, cap. 2.

4 Relatório dos trabalhos da Inspetoria Geral de Higiene apud BENCHIMOL, Jaime. Op. cit., p. 181.

5 Cf.: Diretoria Geral de Polícia Administrativa, Arquivo e Estatística. Recenseamento do Rio de Janeiro (Districto Federal): Realizado em 20 de setembro de 1906. Rio de Janeiro: Oficina de Estatística, 1907, p. 23. A população marítima da capital federal correspondia a 1\% em 1890.

6 AGCRJ, Códice 33.1.2, Logradouros Públicos - Freguesias do E. Novo, Inhaúma e Irajá. Melhoramentos. (1891-1892).

7 AGCRJ, Códice 46.2.70, Melhoramentos em Irajá e Jacarepaguá. (1891). 
No bojo das discussões sobre a necessidade de reformar a estrutura da cidade, as habitações coletivas tornaram-se alvos preferenciais de perseguição por parte da municipalidade e da polícia. Casas de cômodos, cortiços e estalagens passaram a ser vistos como um dos principais focos para a proliferação de doenças, bem como o espaço onde viviam as "classes perigosas". ${ }^{8}$ No alvorecer do regime republicano, durante a breve administração de Barata Ribeiro, a demolição do famoso cortiço Cabeça de Porco marcou o período.

Ao longo da década de 1890 , é possível notar também uma preocupação do poder público municipal em controlar as construções e reconstruções na cidade, especialmente na área urbana. Nessa época, vários decretos e posturas foram aprovados definindo restrições para a edificação ou reforma de prédios nos distritos urbanos. Tais regulamentos dificultaram, principalmente, a execução de melhorias em cortiços e estalagens. Para a área suburbana, todavia, os habitantes não precisavam solicitar licença de construção, tampouco pagar emolumentos. De acordo com a resolução de 17 de junho de 1893, a única orientação para as obras realizadas nessa região era a de que os prédios precisavam ficar três metros afastados do alinhamento das ruas. Ou seja, no final do século XIX, a atenção da municipalidade estava voltada, sobretudo, para os distritos urbanos, ainda que os subúrbios começassem a despertar o interesse de pessoas dispostas a construir habitações coletivas e casas para operários. A própria instalação de diversas estações de trens nos subúrbios contribuiu para a sua ocupação.

Porém, o que realmente impulsionou o crescimento dessa área da cidade foi a realização das reformas urbanas durante a administração do presidente Rodrigues Alves e do prefeito Pereira Passos, no início do século XX. Em razão delas, o traçado da região central e portuária do Rio de Janeiro foi alterado consideravelmente. Ruas foram alargadas, avenidas foram construídas, prédios foram demolidos, o porto foi ampliado e revitalizado. Tamanha reforma teve grande impacto na vida daqueles que moravam na região, habitada, em sua maioria, por trabalhadores - que residiam em cortiços e estalagens - e por pequenos proprietários e comerciantes. Estavam entre as alternativas de moradia para as pessoas que foram obrigadas a sair da área renovada: a busca por habitações coletivas remanescentes, a ocupação dos morros próximos ao centro ou a ida para os subúrbios.

Tal processo de transformação urbana foi objeto de estudo de vários autores ${ }^{9}$, sendo a obra Pereira Passos: um Haussmann Tropical, de Jaime Benchimol, a referência clássica dentre os trabalhos produzidos ao longo da década de $1980 .^{10}$ Pautado em uma vasta pesquisa empírica, o autor apresentou informações sobre os diversos contratos assinados pela municipalidade, bem como as concessões realizadas. Detalhou aspectos da infraestrutura da cidade antes e após as reformas, assim como descreveu minuciosamente as obras empreendidas. Em termos teóricos, partiu de um instrumental marxista para interpretar os motivos que levaram à realização do projeto de renovação urbana. Do seu ponto de vista, a reestrutu-

8 A respeito da perseguição aos cortiços no final do século XIX, ver: CHALHOUB, Sidney. Op. cit., cap. 1.

9 Diversos autores investigaram o processo de reforma urbana no Rio de Janeiro. Merecem destaque as seguintes obras: PECHMAN, Sérgio; FRITSCH, Lilian. "A reforma urbana e seu avesso: algumas considerações a propósito da modernização do Distrito Federal na virada do século”. Revista Brasileira de História. São Paulo: Marco Zero, v. 5, n. 8/9, p. 139-195, set.1984/abr.1985; CARVALHO, Lia de Aquino. Contribuição ao estudo das habitações populares: Rio de Janeiro, 1886-1906. Rio de Janeiro: Secretaria Municipal de Cultura, Departamento Geral de Documentação e Informação Cultural, 1986; ROCHA, Oswaldo Porto. A era das demolições: cidade do Rio de Janeiro, 1870-1920. Rio de Janeiro: Secretaria Municipal de Cultura, Departamento Geral de Documentação e Informação Cultural, 1986; ABREU, Maurício de A. A evolução urbana do Rio de Janeiro. Rio de Janeiro: IPLANRIO \& Zahar, 1987.

10 BENCHIMOL, Jaime. Op. cit. 
ração da cidade estava diretamente relacionada à transição do sistema escravista para o capitalista. Como no início do século XX a utilização do espaço urbano não atendia mais aos interesses dos capitalistas estrangeiros e brasileiros, nem aos do Estado republicano, elas foram realizadas. A passagem a seguir é exemplar da tese defendida por Benchimol:

[...] a operação de renovação urbana tinha em mira: a criação de uma estrutura portuária condizente com o volume, a velocidade e a qualidade do movimento comercial de exportação e importação que constituía a base da vida econômica do Rio de Janeiro; criação de vias de comunicação compatíveis com o volume e a velocidade da circulação de cargas e homens no âmbito da própria cidade; erradicação das frequentes epidemias, em particular a febre amarela, que ceifavam a vida de milhares de pessoas, comprometendo o êxito da política de estímulo à imigração, além de colocar em permanente risco vidas no seio das próprias classes dominantes; a estratificação do espaço urbano carioca e a criação de espaços destinados ao lazer e ao desfrute das classes dominantes."

Em sua análise, o autor destaca o papel do Estado nesse processo de transformação urbana, apontando diferenças em relação ao século XIX. Até então, o poder público deixava sob responsabilidade da iniciativa privada a realização de obras, por meio de concessões, que geralmente tinham natureza especulativa e não resultavam em melhorias. Durante a administração de Pereira Passos e Rodrigues Alves, o Estado tomou para si a tarefa de empreender as obras de renovação urbana. Tal intervenção, de amplitude inédita, representou

[...] a expropriação ou segregação de um conjunto socialmente diferenciado de ocupantes de um espaço determinado da cidade - modificado pela ação do Estado - e sua apropriação por outras frações de classe. Essa "transferência" realizou-se por intermédio de mecanismos de expropriação e valorização acionados diretamente pelo Estado. ${ }^{12}$

Como bem destacou Benchimol, a ação do Estado contribuiu decisivamente para a redistribuição demográfica no âmbito da cidade, uma vez que muitos habitantes dos distritos centrais e da zona portuária não puderam mais residir nessa região da cidade. Ao compararmos os dados dos recenseamentos de 1890 e 1906, podemos notar o processo de mobilidade espacial que se deu na capital federal. Em 1890, 92.906 pessoas residiam nos subúrbios. Dezesseis anos depois, essa população duplicou, atingindo 185.687 habitantes. No caso dos distritos urbanos, o crescimento foi de aproximadamente $46 \%$, pois sua população passou de 425.386 habitantes para 619.648. Distritos centrais, como Candelária e Sacramento, diretamente atingidos pelas obras de renovação, sofreram decréscimos populacionais de $54 \%$ e $20 \%$, respectivamente. Entretanto, distritos mais afastados do centro, como Engenho Velho e Engenho Novo, aumentaram 147\% e 126\%. Na zona suburbana, Inhaúma cresceu $293 \%$ e Irajá, 109\%. ${ }^{13}$

A despeito da amplitude das pesquisas desenvolvidas, que enfocaram principalmente o desenrolar das reformas e quais grupos sociais foram beneficiados ou prejudicados, ainda é possível explorar questões pertinentes ao tema. A admi-

11 BENCHIMOL, Jaime. Op. cit., p. 317.

12 BENCHIMOL, Jaime. Op. Cit., p. 245.

13 Diretoria Geral de Polícia Administrativa, Arquivo e Estatística. Recenseamento do Rio de Janeiro (Districto Federal): Realizado em 20 de setembro de 1906. Rio de Janeiro: Oficina de Estatística, 1907, p. 23. 
nistração de Pereira Passos não foi marcante apenas por ter demolido inúmeros prédios e ter dado ares europeizados ao Rio de Janeiro. Sem dúvida, esse foi o seu aspecto mais visível. Entretanto, durante a sua gestão, a ação fiscalizadora do poder público, bem como a cobrança de impostos aumentaram consideravelmente.

Sendo assim, esse artigo tem dois objetivos principais. O primeiro deles é traçar um panorama a respeito da aplicação de multas por infração de posturas no Distrito Federal, no início da administração de Pereira Passos, atentando para as diferenças entre os distritos urbanos e suburbanos. Ao identificar as especificidades dessas duas áreas, pretendo ampliar o olhar sobre o processo de renovação urbana, uma vez que a historiografia relacionada ao tema privilegiou as mudanças ocorridas nos distritos centrais e portuários. Dado que uma quantidade significativa de pessoas, dentre elas muitos trabalhadores, acabaram se mudando para os distritos mais afastados do centro e também para os subúrbios, é fundamental deslocar o foco de análise para outras regiões da cidade. Por isso, darei ênfase à análise da aplicação de multas nos subúrbios, identificando em quais áreas a fiscalização era mais intensa e quais eram as infrações mais recorrentes.

Esse artigo também tem como propósito apresentar os embates que ocorreram nos subúrbios - sobretudo no distrito de Inhaúma, em razão da aplicação de multas relacionadas à construção - e as estratégias dos trabalhadores suburbanos diante delas. Além de ter sido o distrito que mais cresceu, em termos proporcionais, entre 1890 e 1906, o número de trabalhadores em Inhaúma aumentou consideravelmente. Em 1890, aqueles que trabalhavam na indústria somavam apenas 815 indivíduos, porém, em 1906, eles passaram a representar 10\% de toda a categoria, atingindo a quantia de 11.240 operários. Com isso, Inhaúma tornou-se o distrito carioca com o maior número de trabalhadores da indústria. Os empregados em serviços domésticos também compunham uma parte importante de sua população, pois, em 1890, correspondiam a 1.343 pessoas e subiram para 8.709 , em 1906. Nesta última data, jornaleiros e trabalhadores braçais correspondiam a 9.403 indivíduos. Essas três categorias somadas correspondiam a $81 \%$ dos habitantes de Inhaúma que declararam a sua ocupação no recenseamento de 1906 . Ou seja, após o período das reformas, Inhaúma tornou-se uma área de residência de muitos trabalhadores.

Como veremos com mais detalhes adiante, durante a administração de Pereira Passos, esse distrito foi incluído na cobrança de emolumentos para a construção ou reconstrução de edifícios. Até então, em nenhum distrito suburbano era necessário requerer licença para a realização de obras. Com a mudança na legislação e a consequente autuação de indivíduos que a descumpriam, muitos trabalhadores recorreram ao prefeito para evitar o pagamento das dívidas. A partir da análise desses requerimentos, acompanharemos os conflitos decorrentes da fiscalização municipal em Inhaúma.

\section{A aplicação de multas por infração de posturas no início da administração de Pereira Passos}

As posturas eram regulamentos elaborados pela Intendência Municipal (Poder Legislativo) para normatizar diversos aspectos da vida urbana. Definiam, por exemplo, regras e valores para a obtenção de vários tipos de licença, tais como a abertura de estabelecimento comercial, a construção de prédios, o exercício do comércio ambulante, entre outros. Também determinavam restrições em relação 
à comercialização de produtos, como a proibição da exposição de mercadorias na porta dos estabelecimentos e a obrigatoriedade da aferição dos pesos usados no comércio. Interferiam ainda nas relações de trabalho, uma vez que passaram a proibir o funcionamento das casas de comércio aos domingos, após o meio-dia, e determinaram que motorneiros deveriam realizar exames para a execução de suas funções. Versavam também sobre os usos do espaço urbano, ao normatizar o corte de matas, bem como definiam prescrições sanitárias, ao proibir o depósito de lixo em via pública ou o despejo das águas servidas.

No início do regime republicano, a infração a tais posturas era punida com o pagamento de multas e até mesmo com a prisão temporária do infrator, segundo a Lei n. ${ }^{\circ} 85$, de 20 de setembro de 1892, que reorganizou a administração municipal. As multas poderiam atingir até $200 \$ 000$ (duzentos mil réis) e a prisão poderia ser de até cinco dias. A observância dessa legislação, assim como a elaboração dos autos de infração era realizada pelos agentes da Prefeitura, que tinham como seus auxiliares os guardas do distrito.

Dez anos mais tarde, Rodrigues Alves promulgou novo regulamento a respeito da organização do Distrito Federal assim que assumiu a presidência do país. Segundo a Lei n.o 939, de 29 de dezembro de 1902, as multas aplicadas poderiam chegar a 1:000\$000 (um conto de réis) e os infratores poderiam ser presos por até quinze dias. Além disso, chama a atenção os dispositivos legais disponibilizados ao Conselho Municipal, que poderia deliberar sobre

a cassação de licença, fechamento, interdição, destelhamento e demolição de prédios, obras e construções, apreensão, destruição dos bens apreendidos e venda deles por conta e risco de seus donos, despejo, sequestro e venda de objetos para indenização de despesas feitas. ${ }^{14}$

Tais prerrogativas denotam o respaldo presidencial à ação do Poder Legislativo do Distrito Federal, especialmente no que diz respeito ao gerenciamento do espaço urbano. Ao permitir que o Conselho Municipal pudesse legislar sobre todas essas questões, Rodrigues Alves preparou o arcabouço jurídico necessário para a realização das reformas urbanas. Vale notar, entretanto, que todas essas prerrogativas só começariam a valer após a eleição dos intendentes, que deveria ser realizada em seis meses. Até lá, a administração do Distrito Federal ficaria sob a responsabilidade do prefeito, que gozaria de plenos poderes para administrar a capital federal, exceto o de criar e elevar impostos. Um dia após a sanção dessa lei, Pereira Passos foi nomeado prefeito da cidade. Durante o primeiro semestre de seu mandato, uma série de posturas municipais foram revistas ou criadas e entraram em vigor.

Para termos noção da especificidade da atuação da poder público municipal durante a administração de Pereira Passos, no que diz respeito à aplicação de multas por infração de posturas, apresento a seguir um exercício comparativo, que tomou como base os balancetes da Prefeitura, entre 1901 e $1903 .{ }^{15}$

14 Lei n.o 939, de 29 de dezembro de 1902. Art. 7. $\$ 1 .^{\circ}$.

15 Antes mesmo de ser contratada pela Prefeitura do Distrito Federal para a publicação dos seus atos oficiais, a Gazeta de Notícias já divulgava o balancete de receita e despesa do Rio de Janeiro. O contrato firmado entre as partes foi publicado pelo próprio periódico, em 3 de maio de 1901, p. 2. 
Tabela 1 - Multas arrecadadas por infração de posturas (1901 - 1903)

\begin{tabular}{|cccc}
\hline & 1901 & 1902 & 1903 \\
\hline Janeiro & - & $90 \$ 000$ & $9: 393 \$ 500$ \\
\hline Fevereiro & - & $5: 565 \$ 600$ & $12: 515 \$ 200$ \\
\hline Março & $17: 565 \$ 100$ & $6: 421 \$ 800$ & $18: 904 \$ 400$ \\
Abril & $13: 663 \$ 300$ & $9: 679 \$ 600$ & $18: 403 \$ 000$ \\
\hline Maio & $21: 408 \$ 916$ & $7: 106 \$ 200$ & $29: 058 \$ 500$ \\
\hline Junho & $19: 640 \$ 100$ & $5: 413 \$ 900$ & $17: 203 \$ 500$ \\
\hline Julho & $9: 101 \$ 850$ & $9: 315 \$ 400$ & $23: 177 \$ 000$ \\
Agosto & $8: 342 \$ 420$ & $9: 113 \$ 500$ & $16: 539 \$ 100$ \\
Setembro & $13: 903 \$ 600$ & $6: 270 \$ 500$ & $21: 815 \$ 100$ \\
\hline Outubro & $9: 787 \$ 560$ & $6: 772 \$ 900$ & $24: 039 \$ 900$ \\
Novembro & $7: 534 \$ 400$ & $5: 128 \$ 994$ & $22: 370 \$ 880$ \\
Dezembro & $3: 402 \$ 340$ & $4: 317 \$ 300$ & $15: 513 \$ 100$ \\
\hline Total & $124: 349 \$ 586$ & $75: 195 \$ 694$ & $228: 933 \$ 180$ \\
\hline
\end{tabular}

Ainda que as informações referentes ao ano de 1901 estejam incompletas, é possível chegar a algumas conclusões. No primeiro ano considerado, o valor arrecadado com as multas oscilou bastante. No mês de dezembro, a arrecadação foi quase sete vezes menor do que a do mês de maio. Em 1902, o montante obtido mensalmente diminuiu significativamente, se comparado ao ano anterior. Em nenhum mês a marca dos 10:000\$000 (10 contos de réis) foi atingida. Mesmo sem os valores referentes aos meses de janeiro e fevereiro, em 1901, o valor total arrecadado foi $65 \%$ maior do que o de 1902. Em 1903, entretanto, sob a administração de Pereira Passos, a arrecadação mensal e anual com multas por infração de posturas aumentou consideravelmente. Triplicou em relação a 1902 e foi 85\% maior em relação a 1901.

Tanto Benchimol como Sérgio Pechman e Lilian Fritsch apontaram para a intensificação da fiscalização municipal a partir do período das reformas urbanas. O primeiro afirmou que essas medidas "serviram para descarregar parte do ônus da 'modernização' sobre a heterogênea plebe carioca”. ${ }^{16}$ Ao apresentar os diversos regulamentos aprovados durante a administração de Pereira Passos, o autor privilegiou as transformações que ocorreram no âmbito da legislação. Deixou de considerar, todavia, os conflitos decorrentes dessa atuação mais incisiva da municipalidade. Partindo do pressuposto de que as reformas urbanas foram um desdobramento inerente à transição do sistema escravista para o capitalista, a população pobre e trabalhadora do Rio de Janeiro foi tratada como vítima desse processo. Nessa perspectiva de análise, portanto, não havia espaço para as tentativas de negociação com o poder público municipal.

Pechman e Fritsch também abordaram as mudanças que ocorreram na legislação carioca. Entretanto, eles procuraram evidenciar que a implementação de novas formas de regulação dos hábitos e costumes levou a população a buscar estratégias para lidar com a nova conjuntura:

O projeto de reforma do Rio proposto pela administração Rodrigues Alves ilustra à perfeição como os setores populares, em certas ocasiões, mesmo não conseguindo barrar a implementação, no seu conjunto, de

16 BENCHIMOL, Jaime. Op. cit., p. 277. 
uma série de medidas oficiais, podem forçar as autoridades à negociação, logrando com isso, minorar os males que Ihes seriam causados. ${ }^{17}$

Para os autores, o repúdio popular a essa intensificação do controle sobre suas práticas se expressou por meio dos motins, do desrespeito às leis e da manutenção de seus hábitos. Ainda que concordassem com a ideia de que a consolidação do capitalismo impulsionou a realização das reformas no Rio de Janeiro, os autores buscaram matizar esse processo, defendendo que a população não aceitou passivamente tais mudanças.

Para ampliar esse debate, faz-se necessário levar em consideração outras formas de atuação da população frente ao aumento do controle por parte da municipalidade. Um caminho para isso tem sido delineado mediante a investigação das estratégias de negociação com o Conselho Municipal e com o próprio prefeito. As queixas e os abaixo-assinados enviados aos meios de comunicação e aos intendentes, assim como os recursos e questionamentos remetidos ao chefe do Executivo dão indícios dos conflitos oriundos do recrudescimento da legislação municipal e demonstram, ao mesmo tempo, o aspecto relacional desse processo. Os habitantes não aceitaram tacitamente as reformas. Ainda que trabalhadores e pobres em geral não estivessem em condições de barrar o projeto de renovação urbanística, eles buscaram expressar o seu descontentamento, assim como empreenderam esforços para minimizar o seu impacto.

Dependendo da região da cidade onde se residia, a cobrança de impostos podia variar. Sendo assim, apresento a seguir os dados a respeito das multas arrecadadas nas áreas urbanas e suburbanas do Rio de Janeiro, em 1903:

Tabela 2 - Multas arrecadadas por infração de posturas no Distrito Federal, segundo distritos urbanos e suburbanos $(1903)^{18}$

\begin{tabular}{|c|c|c|c|c|c|}
\hline & \multicolumn{2}{|c|}{ Distritos Urbanos } & \multicolumn{2}{|c|}{ Distritos Suburbanos } & \multirow{2}{*}{ Total mensal } \\
\hline & Arrecadação mensal & $\%$ & Arrecadação mensal & $\%$ & \\
\hline Janeiro & $8: 265 \$ 940$ & $94 \%$ & $520 \$ 500$ & $6 \%$ & $8: 786 \$ 440$ \\
\hline Fevereiro & $7: 413 \$ 100$ & $86 \%$ & $1: 236 \$ 500$ & $14 \%$ & $8: 649 \$ 600$ \\
\hline Março & 10:879\$800 & $93 \%$ & $803 \$ 500$ & $7 \%$ & $11: 683 \$ 300$ \\
\hline Abril & $11: 457 \$ 900$ & $88 \%$ & $1: 557 \$ 520$ & $12 \%$ & $13: 015 \$ 420$ \\
\hline Maio & 18:683\$700 & $93 \%$ & $1: 319 \$ 600$ & $7 \%$ & $20: 003 \$ 300$ \\
\hline Junho & $10: 830 \$ 500$ & $83 \%$ & $2: 216 \$ 000$ & $17 \%$ & $13: 046 \$ 500$ \\
\hline Julho & $15: 133 \$ 500$ & $94 \%$ & $1: 040 \$ 500$ & $6 \%$ & 16:174\$000 \\
\hline Agosto & 11:791\$100 & $96 \%$ & $523 \$ 500$ & $4 \%$ & $12: 314 \$ 600$ \\
\hline Setembro & 13:808\$000 & $95 \%$ & $663 \$ 000$ & $5 \%$ & 14:471\$000 \\
\hline Outubro & $12: 234 \$ 600$ & $92 \%$ & $1: 126 \$ 000$ & $8 \%$ & $13: 360 \$ 600$ \\
\hline Novembro & 11:894\$600 & $88 \%$ & 1:653\$000 & $12 \%$ & $13: 547 \$ 600$ \\
\hline Dezembro & $9: 820 \$ 700$ & $90 \%$ & $1: 054 \$ 300$ & $10 \%$ & 10:875\$000 \\
\hline Total anual & $142: 213 \$ 440$ & $91 \%$ & $13: 713 \$ 920$ & $9 \%$ & $155: 927 \$ 360$ \\
\hline
\end{tabular}

17 PECHMAN, Sérgio; FRITSCH, Lilian. Op. cit, p. 178.

18 Em 16 de junho de 1903, foi promulgado o Decreto n. ${ }^{\circ} 434$, que reorganizou a divisão territorial do Distrito Federal. Até aquela data, o Rio de Janeiro contava com 27 distritos, dos quais 10 eram considerados suburbanos. Após o referido decreto, passou a ter 25 distritos, sendo 7 suburbanos. As equivalências necessárias foram realizadas para a elaboração da tabela. Ao longo do artigo, prevaleceu a organização adotada a partir do Decreto n..$^{\circ} 434$. 
Antes de dar início à análise, é importante esclarecer que mensalmente a Prefeitura publicava nas páginas da Gazeta de Notícias tanto o balancete de receitas e despesas como um quadro demonstrativo das multas arrecadadas por distrito, o que permitiu a elaboração da Tabela 2. Como é possível notar, os valores totais mensais provenientes desses quadros não correspondem aos montantes também mensais que apareceram na Tabela 1. Nenhuma informação que justificasse essa diferença foi encontrada na seção que publicava os atos oficiais da municipalidade.

A despeito dessas incompatibilidades, é bastante evidente a diferença entre o valor arrecadado com as multas nas áreas urbana e suburbana. Durante o ano de 1903, o mês com o maior percentual de pagamento de multas nos distritos suburbanos foi junho, com 17\%. Alguns aspectos devem ser considerados para entender essa discrepância. O primeiro deles está relacionado à diferença nos impostos, segundo a área de residência. De acordo com o Decreto $n .^{\circ} 391$, a cobrança de emolumentos para a construção, reconstrução e reforma de prédios incidia sobre toda a área urbana e apenas sobre alguns distritos suburbanos. Como a infração a esse decreto foi um dos principais motivos de autuação durante a administração de Pereira Passos, é fundamental levar em conta esse aspecto para entender a diferença entre as multas pagas pelos moradores dos distritos urbanos e suburbanos.

Outro fato a ser considerado diz respeito à quantidade de pessoas que residiam em cada uma das áreas. Tomando como base os recenseamentos de 1890 e 1906, os suburbanos correspondiam a $18 \%$ da população do Distrito Federal em 1890 e atingiram $23 \%$ em $1906 .{ }^{19}$ Ou seja, havia um contingente bem maior de pessoas nos distritos urbanos do que nos suburbanos, o que leva a crer que a possibilidade de autuação era maior no caso dos primeiros. Vale observar ainda que a área dos distritos urbanos era menor, o que deve ter facilitado o trabalho de fiscalização dos funcionários municipais responsáveis pela aplicação das multas.

Além da diferença entre os distritos urbanos e suburbanos, a aplicação de multas era mais recorrente em alguns distritos dos subúrbios do que em outros, como pode ser visualizado na tabela a seguir:

\section{Tabela 3 - Multas arrecadadas por infração de posturas, segundo os distritos suburbanos do Rio de Janeiro (1903) ${ }^{20}$}

\begin{tabular}{l|c|c|c|c|c|c|c|c|c|c|}
\multicolumn{3}{|c}{$1^{\circ}$ tri } & \multicolumn{9}{c}{$2^{\circ}$ tri } \\
& $\begin{array}{l}\text { Valor } \\
\text { arrecadado }\end{array}$ & $\%$ & $\begin{array}{c}\text { Valor } \\
\text { arrecadado }\end{array}$ & $\%$ & $\begin{array}{c}\text { Valor } \\
\text { arrecadado }\end{array}$ & $\%$ & $\begin{array}{c}\text { Valor } \\
\text { arrecadado }\end{array}$ & $\%$ & $\begin{array}{c}\text { Valor } \\
\text { porrecadado }\end{array}$ & $\%$ \\
\hline Inhaúma & $478 \$ 000$ & $19 \%$ & $1: 652 \$ 000$ & $32 \%$ & $557 \$ 000$ & $25 \%$ & $2: 924 \$ 300$ & $76 \%$ & $5: 611 \$ 300$ & $41 \%$ \\
\hline Irajá & $760 \$ 000$ & $30 \%$ & $943 \$ 600$ & $19 \%$ & $240 \$ 500$ & $11 \%$ & $198 \$ 500$ & $5 \%$ & $2: 142 \$ 600$ & $16 \%$ \\
\hline Jacarepaguá & $310 \$ 000$ & $12 \%$ & $172 \$ 000$ & $3 \%$ & $77 \$ 000$ & $3 \%$ & $76 \$ 000$ & $2 \%$ & $635 \$ 000$ & $5 \%$ \\
\hline Campo & $296 \$ 000$ & $12 \%$ & $1: 140 \$ 000$ & $22 \%$ & $556 \$ 000$ & $25 \%$ & $268 \$ 000$ & $7 \%$ & $2: 260 \$ 000$ & $16 \%$ \\
\hline Grande & $24 \$ 000$ & $1 \%$ & $685 \$ 000$ & $13 \%$ & $160 \$ 000$ & $7 \%$ & $12 \$ 000$ & $0 \%$ & $881 \$ 000$ & $6 \%$ \\
\hline Guaratiba & $672 \$ 500$ & $26 \%$ & $480 \$ 520$ & $9 \%$ & $454 \$ 500$ & $20 \%$ & $225 \$ 000$ & $6 \%$ & $1: 832 \$ 520$ & $13 \%$ \\
\hline Santa Cruz & $20 \$ 000$ & $1 \%$ & $20 \$ 000$ & $0 \%$ & $182 \$ 000$ & $8 \%$ & $129 \$ 500$ & $3 \%$ & $351 \$ 500$ & $3 \%$ \\
\hline
\end{tabular}

19 Diretoria Geral de Polícia Administrativa, Arquivo e Estatística. Recenseamento do Rio de Janeiro (Districto Federal): Realizado em 20 de setembro de 1906. Rio de Janeiro: Oficina de Estatística, 1907, p. 23.

20 Tabela elaborada com base nos quadros demonstrativos das multas arrecadadas em cada distrito e publicados quinzenalmente ao longo de 1903, exceto nos casos de janeiro e fevereiro, cujas publicações foram mensais. Esses dados também foram utilizados para a construção da Tabela 4. 
A partir desses números, é possível notar que na zona suburbana os habitantes de Inhaúma foram os que mais pagaram multas por infração de posturas ao longo de 1903 , atingindo a cifra de $41 \%$ do total enviado aos cofres municipais. Chama a atenção, inclusive, o $4 .^{\circ}$ trimestre, onde Inhaúma foi responsável por $76 \%$ do montante pago. Seguem com uma arrecadação intermediária os distritos de Irajá, Campo Grande e Santa Cruz. Os distritos que tiveram um número pequeno de autuações foram Guaratiba, Jacarepaguá e Ilhas.

Existem algumas razões para que os habitantes de Inhaúma tenham sido mais multados. Esse foi o distrito que mais cresceu, em termos demográficos, entre 1890 e 1906, pois era o mais próximo da área urbana. Sua população passou de 17.448 habitantes para 68.557 no período. Outros distritos também tiveram um aumento populacional considerável, tais como Irajá e Campo Grande. Aquele passou de 13.130 habitantes para 27.410. O último, por sua vez, possuía 15.950 moradores em 1890 e subiu para 31.248 em 1906. ${ }^{21}$ Os percentuais de crescimento dos três distritos foram, respectivamente: $293 \%$, 109\% e 96\%. Tanto em números absolutos como em termos percentuais, esses três distritos foram os que mais destacaram na zona suburbana. Tal aumento demográfico foi acompanhado pelo crescimento predial. Vejamos:

Tabela 4 - Crescimento predial na zona suburbana (1890-1906) $)^{22}$

\begin{tabular}{lccc} 
& \multicolumn{3}{c}{ Número de domicílios } \\
\hline Inhaúma & 1890 & 1906 & Diferença em $n^{\text {os }}$ absolutos \\
\hline Irajá & 2.315 & 9.140 & 6.825 \\
Jacarepaguá & 1.614 & 4.201 & 2.587 \\
Campo Grande & 1.324 & 1.947 & 623 \\
Guaratiba & 1.868 & 3.905 & 2.037 \\
Santa Cruz & 1.335 & 2.868 & 1.533 \\
Ilha do Governador & 1.203 & 1.844 & 641 \\
Paquetá & 563 & 837 & 274 \\
\hline Total & 285 & 306 & 21 \\
\hline
\end{tabular}

Como é possível notar, Inhaúma tem um aumento acentuado no número de prédios, seguido por Irajá e Campo Grande. Uma característica interessante deve ser considerada para compreender o aumento demográfico e predial especificamente nesses distritos: a Estrada de Ferro Central do Brasil cruzava seus territórios. Sem dúvida, essa alternativa de transporte pesava na escolha do local de moradia, sobretudo quando a possibilidade de residir nos distritos centrais tornava-se cada vez menor, em razão das reformas. Dado que nem todos os distritos suburbanos contavam com linhas férreas, a existência delas foi um diferencial para a ocupação da região, contribuindo para que alguns distritos fossem mais populo-

21 Diretoria Geral de Polícia Administrativa, Arquivo e Estatística. Recenseamento do Rio de Janeiro (Districto Federal): Realizado em 20 de setembro de 1906. Rio de Janeiro: Oficina de Estatística, 1907, p. 23.

22 Cf:: Ministério da Indústria, Viação e Obras Públicas, Diretoria Geral de Estatística. Recenseamento geral da Republica dos Estados Unidos do Brazil em 31 de dezembro de 1890 (Districto Federal). Rio de Janeiro: Tipografia Leuzinger, 1895, p. 424-5; Diretoria Geral de Polícia Administrativa, Arquivo e Estatística. Recenseamento do Rio de Janeiro (Districto Federal): Realizado em 20 de setembro de 1906. Rio de Janeiro: Oficina de Estatística, 1907, p. 36-7. 
sos do que outros. Jacarepaguá, por exemplo, era mais próximo do centro do que Campo Grande, mas não contava com linhas férreas. Entre 1890 e 1906, teve um crescimento predial bem menor que Campo Grande.

Além de divulgar os balancetes de receita e despesa da Prefeitura e os quadros demonstrativos das multas arrecadadas por distrito, a municipalidade passou a publicar também os nomes dos infratores, seus endereços, os motivos pelos quais foram autuados e os valores das multas. ${ }^{23}$ Ao longo do primeiro ano de mandato de Pereira Passos, foram 460 autuações na zona suburbana:

Tabela 5 - Multas aplicadas e recebidas nos distritos suburbanos (1903)

\begin{tabular}{lccc}
\multicolumn{1}{c}{ Distritos } & $\begin{array}{c}\text { Valor das multas } \\
\text { aplicadas }\end{array}$ & $\begin{array}{c}\text { Valor recebido } \\
\text { pelas multas }\end{array}$ & $\begin{array}{c}\text { \% do valor pago (em } \\
\text { relação ao valor } \\
\text { total) }\end{array}$ \\
\hline Inhaúma & $20: 221 \$ 000$ & $5: 611 \$ 300$ & $28 \%$ \\
\hline Irajá & $7: 560 \$ 000$ & $2: 142 \$ 600$ & $28 \%$ \\
Jacarepaguá & $7: 486 \$ 000$ & $635 \$ 000$ & $8 \%$ \\
Campo Grande & $4: 460 \$ 000$ & $2: 260 \$ 000$ & $51 \%$ \\
Guaratiba & $4: 870 \$ 000$ & $881 \$ 000$ & $18 \%$ \\
Santa Cruz & $940 \$ 000$ & $1: 832 \$ 520$ & $195 \%$ \\
Ilhas & $2: 790 \$ 000$ & $351 \$ 500$ & $13 \%$ \\
\hline Total & $48: 327 \$ 000$ & $\mathbf{1 3} 2713 \$ 920$ & $28 \%$
\end{tabular}

Esses dados são muito reveladores, pois mostram que o valor correspondente ao total de multas aplicadas (48:527\$000 - quarenta e oito contos e quinhentos e vinte e sete mil réis) é quase quatro vezes o total arrecadado. Excetuando o caso do distrito de Santa Cruz, em todos os outros o montante pago foi bem inferior ao valor das autuações. Ainda que possam existir incoerências nos números divulgados pela Prefeitura, especialmente no que diz respeito ao valor recebido pelas multas, tudo indica que, em 1903, houve uma intensa fiscalização por parte da municipalidade. A despeito disso, em muitos casos, os esforços dos agentes municipais não resultaram na devida ampliação de receita nos cofres municipais, dada a significativa diferença entre as multas aplicadas e recebidas.

Ao separarmos as autuações por distrito e segundo as principais infrações, foi possível identificar características relevantes para compreender as especificidades dentro do próprio subúrbio. Observemos:

Tabela 6 - Principais multas aplicadas nos distritos suburbanos $(1903)^{24}$

(Continua)

\begin{tabular}{l|ccccccc|c}
\hline & Inhaúma & Irajá & Jacarepaguá & $\begin{array}{c}\text { Campo } \\
\text { Grande }\end{array}$ & $\begin{array}{c}\text { Guaratiba } \\
\text { Cruz }\end{array}$ & $\begin{array}{c}\text { Santa } \\
\text { Ilhas }\end{array}$ & Total \\
\hline $\begin{array}{l}\text { Irregularidades sanitárias } \\
\begin{array}{l}\text { Estabelecimentos comerciais } \\
\text { sem licença ou irregulares }\end{array}\end{array}$ & $9,8 \%$ & - & $0,6 \%$ & $0,2 \%$ & $0,8 \%$ & - & $0,2 \%$ & $\mathbf{1 1 , 7 \%}$ \\
\hline
\end{tabular}

23 A publicação dos nomes dos infratores foi determinada pelo art. 19 da Lei n. ${ }^{\circ}$ 939, de 29 de dezembro de 1902, a mesma lei que reorganizou a administração municipal logo após a posse de Rodrigues Alves.

24 As porcentagens foram calculadas com base nos valores das multas aplicadas. 
Tabela 6 - Principais multas aplicadas nos distritos suburbanos (1903)

\begin{tabular}{|c|c|c|c|c|c|c|c|c|}
\hline & Inhaúma & Irajá & Jacarepaguá & $\begin{array}{l}\text { Campo } \\
\text { Grande }\end{array}$ & Guaratiba & $\begin{array}{l}\text { Santa } \\
\text { Cruz }\end{array}$ & Ilhas & Total \\
\hline $\begin{array}{l}\text { Obras de construção sem } \\
\text { licença ou irregulares }\end{array}$ & $15,7 \%$ & $5 \%$ & - & $0,2 \%$ & - & - & $0,2 \%$ & $21,1 \%$ \\
\hline Corte de matas sem licença & - & $2,1 \%$ & $5,8 \%$ & $1,7 \%$ & $7,4 \%$ & - & - & $17 \%$ \\
\hline $\begin{array}{l}\text { Veículos sem licença e/ou } \\
\text { irregulares }\end{array}$ & - & - & $7,3 \%$ & - & - & - & $1 \%$ & $8,4 \%$ \\
\hline $\begin{array}{l}\text { Vendedores ambulantes } \\
\text { sem licença }\end{array}$ & $1 \%$ & $1,3 \%$ & - & - & - & $0,4 \%$ & $0,4 \%$ & $3,1 \%$ \\
\hline Outros & $1,1 \%$ & $2,3 \%$ & - & $0,6 \%$ & - & - & $0,4 \%$ & $4,5 \%$ \\
\hline Não identificado & $2,4 \%$ & $0,2 \%$ & $0,7 \%$ & $0,5 \%$ & - & - & $1,5 \%$ & $5,3 \%$ \\
\hline Total & $41,8 \%$ & $15,6 \%$ & $15,5 \%$ & $9,2 \%$ & $10,1 \%$ & $1,9 \%$ & $5,8 \%$ & $100 \%$ \\
\hline
\end{tabular}

O principal motivo que levou os suburbanos a serem autuados foi o da falta de licença para o funcionamento de estabelecimentos comerciais. Diversos proprietários foram multados por terem iniciado atividade comercial sem a devida permissão, por não terem feito a sua renovação, porque mudaram de endereço sem aguardar autorização para tal ou porque colocaram letreiros ou mastros em frente aos seus negócios sem solicitarem licença. Também foram autuados os proprietários que não cumpriam os horários para o fechamento de portas ou cujos estabelecimentos apresentavam irregularidades, tais como a falta de esterilizador (no caso dos barbeiros), a exposição de alimentos às moscas, ao pó ou nas ombreiras das portas, a ausência dos jogos de pesos ou porque eles não estavam devidamente aferidos.

Inhaúma aparece como o distrito que mais recebeu esse tipo de autuação, seguido por Campo Grande e Irajá. Embora poucas multas desse tipo tenham sido aplicadas nos demais distritos, todos eles tiveram autuações. Esses dados dão indícios, portanto, de que o crescimento populacional vivenciado pela região foi acompanhado pela ampliação dos serviços existentes e, consequentemente, da oferta de locais de trabalho no próprio subúrbio. Mais uma vez, verificamos que nas áreas que contavam com as linhas férreas a expansão da atividade comercial foi maior.

A falta de licença para a realização de obras foi o segundo motivo pelo qual os suburbanos foram autuados. Nesse caso, as multas foram aplicadas majoritariamente em Inhaúma e Irajá. Para entender por que apenas esses distritos receberam esse tipo de autuação, há que se levar em consideração, novamente, a especificidade do Decreto n. ${ }^{\circ} 391$. Observemos:

Artigo $10^{\circ}$ Nenhuma obra de construção, reconstrução, acréscimos e modificações de prédios poderá ser começada nas freguesias da Candelária, Santa Rita, Sacramento, S. José, Santo Antônio, Espírito Santo, Santana, Glória, Lagoa, Gávea, S. Cristóvão, Engenho Velho, Engenho Novo, Inhaúma e Irajá sem licença da Prefeitura.

A partir desse decreto, Inhaúma e Irajá foram os únicos distritos suburbanos cujos moradores deveriam requerer licença para a realização de obras de construção ou reconstrução. É por isso que parte considerável desse tipo de multa incidiu sobre esses distritos. A única autuação referente a Campo Grande ocorreu porque o infrator não solicitou autorização para a construção de um coreto no largo da capela, descumprindo o artigo 56 do Decreto n. ${ }^{\circ} 843$. A infração ocorrida na llha de Paquetá, por sua vez, foi aplicada porque um morador não aterrou o seu terreno. 
O terceiro motivo mais recorrente para a aplicação de multas foi o do corte de matas sem licença, proibido segundo o Decreto n. ${ }^{\circ}$ 691, de 17 de julho de 1899. Como é possível notar, essa infração foi aplicada em distritos menos urbanizados, como Guaratiba e Jacarepaguá, o que indica, portanto, que parte da vegetação deles estava provavelmente sendo desmatada para a realização de loteamentos. Por fim, vale observar que as irregularidades sanitárias foram multadas principalmente em Inhaúma, o distrito suburbano que contava com o maior número de habitantes. Estavam entre as infrações o depósito de lixo e água servida em via pública e a falta de limpeza dos quintais.

A grande quantidade de multas não foi casual. A publicação de várias circulares ao longo de 1903, com orientações aos agentes fiscais e guardas de distrito, dão indícios da preocupação de Pereira Passos quanto à devida aplicação das autuações. Em 12 de fevereiro, por exemplo, ele comunicou aos agentes fiscais que a partir daquele momento deveriam observar "escrupulosamente [...] as disposições do Regulamento para o processo administrativo das infrações de posturas, leis e regulamentos municipais", promulgado no dia 4 do mesmo mês. ${ }^{25} \mathrm{Em} 2$ de julho, recomendou que os agentes observassem "com a máxima vigilância no intuito de serem fielmente cumpridas as disposições do dec. $n^{\circ} 444$, de 27 de junho último, que dispõe sobre escavações nas ruas, travessas e praças". ${ }^{26} \mathrm{Em} 25$ de setembro, a seguinte circular foi publicada:

\section{Sr. Agente da Prefeitura no Distrito de ...}

De ordem do Sr. Prefeito do Distrito Federal vos recomendo que é de vosso dever lavrar imediatamente auto de qualquer infração de postura ou lei municipal, embora sejam pagas as multas no ato da contravenção, devendo cessar, por completo, a praxe que seguem alguns Agentes de fazer intimações para o pagamento das mesmas multas, visto constarem essas intimações do próprio auto que deve ser entregue à parte interessada. Saudações. - O Diretor Geral, Dr. A. F. do Amaral. ${ }^{27}$

Essa circular fornece pistas de que o Decreto n. ${ }^{\circ} 395$, de 4 de fevereiro de 1903, já não estava sendo cumprido com o rigor necessário oito meses após ter sido promulgado. Ele continha orientações sobre como os agentes deveriam proceder para realizar as autuações. Para reverter tal situação, Pereira Passos publicou a circular.

No dia $1 .^{\circ}$ de outubro, o expediente dos guardas passou a ser mais longo. De acordo com a Circular n. ${ }^{\circ}$ 90, os agentes deveriam fazer com que eles começassem o serviço da fiscalização desde as primeiras horas do dia e o prolongassem até a noite, "não devendo fazê-lo, como até agora, das 10 da manhã às 4 da tarde". ${ }^{28}$ Não bastasse toda a vigilância sobre a correta execução da legislação municipal, o trabalho dos guardas deveria ser organizado de modo que a população fosse fiscalizada por mais tempo.

Esses são apenas alguns exemplos das circulares publicadas no início da administração de Pereira Passos. Se por um lado elas colocam em evidência os esforços do poder público municipal para garantir a observância dos decretos e das posturas vigentes, por outro, demonstram que o controle não recaiu apenas sobre a população, mas também sobre os próprios funcionários da Prefeitura. A reiteração das circulares, bem como a insistência no fiel cumprimento da legislação em

25 Circular.$^{\circ} 26$, de 12 de fevereiro de 1903.

26 Circular n. ${ }^{\circ} 63$, de 2 de julho de 1903.

27 Circular n. ${ }^{\circ}$ 2.072, de 25 de setembro de 1903.

28 Cf.: Circular n. ${ }^{\circ}$ 90, de 1 de outubro de 1903. 
vigor dão pistas da complexa relação entre habitantes, funcionários municipais e Poder Executivo. Para aprofundarmos a compreensão dessas relações, sobretudo no que diz respeito aos trabalhadores que viviam ou passaram a residir nos subúrbios, trato a seguir da fiscalização das construções, reconstruções e reformas no distrito de Inhaúma.

\section{Tensões entre trabalhadores suburbanos e funcionários municipais: negociações em torno da questão da moradia ${ }^{29}$}

Embora a quantidade de autuações nos subúrbios tenha sido grande, como foi verificado, uma boa parte dos infratores não realizou o pagamento das multas. Um dos principais motivos para esse fato está relacionado aos pedidos de perdão das dívidas, que eram remetidos ao prefeito. Segundo Lea lamashita, no início do Império, a adoção de alguns princípios liberais na Constituição de 1824, e no Código do Processo Criminal de 1832, passou a garantir aos cidadãos a possibilidade de reclamar por escrito ao Poder Legislativo e ao Executivo. ${ }^{30}$

Podemos acompanhar o uso dessa estratégia em estudos como o de Fabiane Popinigis, que investigou a luta dos caixeiros cariocas para garantir a folga aos domingos. Dentre outras formas de reivindicação, eles recorreram à negociação com a Câmara Municipal para a aprovação de uma legislação que lhes assegurasse o descanso. ${ }^{31}$ Paulo Terra, por sua vez, analisou diversos requerimentos enviados à instituição camarária para questionar posturas que regulavam o trânsito na cidade e interferiam diretamente no trabalho de cocheiros e carroceiros. ${ }^{32}$ Tais pesquisas privilegiaram o estudo de categorias profissionais específicas e debateram como a Câmara Municipal pode ser vista como um espaço de disputa e demanda.

No caso das autuações por infrações de posturas, pelo menos desde a década de 1890, era comum recorrer ao chefe do Executivo para tentar evitar o pagamento das multas. Na própria legislação que entrou em vigor em 1903, estava regulamentada a possibilidade de recurso. ${ }^{33}$ Cabia ao prefeito, auxiliado pelos pareceres dos funcionários municipais envolvidos na autuação, avaliar se o suplicante merecia ter a dívida perdoada ou não.

Do panorama apresentado na primeira parte deste artigo, quase $30 \%$ das multas aplicadas nos distritos suburbanos estavam relacionadas à falta de licença dos estabelecimentos comerciais. Como esses negociantes não configuram os sujeitos históricos que privilegio em minha pesquisa, não me detive à análise dos recursos a esse tipo de multa. Levando em consideração o perfil do distrito de Inhaúma, que passou a contar com um grande contingente de trabalhadores do final do século

29 Discuto em detalhes a respeito dessa questão no capítulo 2 de minha dissertação de mestrado, que foi publicada sob o título Viver nos subúrbios: a experiência dos trabalhadores de Inhaúma (Rio de Janeiro, 1890-1910). Rio de Janeiro: Secretaria Municipal de Cultura; Arquivo Geral da Cidade do Rio de Janeiro, 2011.

30 Cf.: IAMASHITA, Lea Maria Carrer. A Câmara Municipal como instituição de controle social: o confronto em torno das esferas pública e privada. Revista do Arquivo Geral da Cidade do Rio de Janeiro. Rio de Janeiro: Secretaria Municipal de Cultura; Arquivo Geral da Cidade do Rio de Janeiro, n. 3, p. 41-56, 2009.

31 Cf.: POPINIGIS, Fabiane. Operários de casaca? Relações de trabalho e lazer no comércio carioca na virada dos séculos XIX e XX. Tese (Doutorado em História Social). Campinas: Unicamp/IFCH, 2003, cap. 2.

32 Cf.: TERRA, Paulo Cruz. Cidadania e trabalho: cocheiros e carroceiros no Rio de Janeiro (1870-1906). Tese (Doutorado em História). Niterói: UFF/ICHF, 2012, cap. 2.

33 Cf.: Decreto n. ${ }^{\circ}$ 395, de 4 de fevereiro de 1903, Art. 9. 
XIX para o início do XX, optei por investigar os conflitos e as estratégias de negociação que se deram em razão da infração à legislação sobre construções, pois, a partir da administração de Pereira Passos, parte dos moradores dos subúrbios começaram a pagar emolumentos para a realização de obras.

Antes de dar início à análise, faz-se necessário apresentar algumas informações a respeito da organização municipal. De acordo com o Decreto n. ${ }^{\circ}$ 399, de 6 de março de 1903, as agências da Prefeitura eram compostas por agentes fiscais e guardas municipais, e eram "repartições subordinadas imediatamente ao Prefeito, destinadas a representá-lo nas divisões territoriais do Distrito Federal”. Entre as atribuições dos agentes estava a de "fazer executar as posturas e deliberações do Conselho", bem como de "lavrar e remeter à autoridade competente os autos de flagrante contra os infratores de posturas". ${ }^{34}$ O prefeito possuía a prerrogativa de designar anualmente os guardas que trabalhariam em cada distrito, podendo removê-los de uma agência para outra, se assim julgasse necessário. Para ser nomeado guarda era imprescindível ser cidadão brasileiro, saber ler e escrever, possuir aptidão para o desempenho da função e ter bom procedimento.

Em 27 de junho de 1903, entrou em vigor o Decreto n. ${ }^{\circ} 445$, que dava novo regulamento à Diretoria Geral de Obras e Viação. Fazia parte de suas atribuições a "superintendência de todos os serviços relativos a obras municipais, carta cadastral, [...] construção, reconstrução, acréscimos e reparos de prédios ou edifícios". Tal diretoria era composta por diversos funcionários, entre eles um diretor-geral, três subdiretores e quinze engenheiros de circunscrição. Cabia aos últimos "velar pelo cumprimento exato das posturas no que for atinente aos serviços de obras a seu cargo, devendo promover os meios de repressão e fazer as devidas comunicações". 35

Isso significa que a população era fiscalizada tanto por agentes e guardas municipais como por engenheiros de circunscrição. Assim, quando um requerimento era enviado ao Prefeito, com o intuito de recorrer de uma multa, ou ele era encaminhado à Diretoria Geral de Obras e Viação, ou à agência da Prefeitura no distrito em questão, para que se prestassem os esclarecimentos necessários. Como duas esferas de poder eram responsáveis pela vigilância das posturas, foi possível perceber que, em diversos momentos, os funcionários a elas subordinados entraram em conflito, porque divergiam a respeito do modo como elas deveriam ser aplicadas. Apresentadas essas informações sobre os possíveis caminhos percorridos pelos recursos remetidos ao chefe do Executivo, comecemos a analisá-los.

Em 11 de maio de 1903, Manoel Silveira Costa Tavares foi autuado pelo agente Luiz Maggessi Corimbaba, pois estava "construindo um acréscimo na casa de sua propriedade" sem a devida licença. ${ }^{36}$ Por ter infringido o art. $1 .{ }^{\circ}$ do Decreto n. ${ }^{\circ} 391$, de 10 de fevereiro de 1903, que determinava que toda obra de "construção, reconstrução, acréscimos ou modificações" deveria ter licença da Prefeitura, Manoel foi multado em 100\$000 (cem mil réis). Em vista disso, três dias depois de autuado, recorreu ao Prefeito:

Exmo. Sr. Dr. Prefeito do Distrito Federal

Manoel Silveira Costa Tavares, residente à rua Dr. Leal n. 66, freguesia de Inhaúma, tendo sido intimado por um auto de infração do respectivo Agente da Prefeitura por estar construindo um acréscimo na casa citada

34 Decreto n. ${ }^{\circ} 399$, de 6 de março de 1903, Art. 5.

35 Decreto n. ${ }^{\circ} 445$, de 27 de junho de 1903, Art. 13.

36 AGCRJ, Códice 10-1-9, Infração de posturas de Inhaúma (1903-1910). 
de sua propriedade, vem submissamente ponderar a V. Exa que não é isso de todo o ponto exato, pois que o pequeno acréscimo que fez em sua casa já vem de longa data, pelo que o suplicante não julga ter infringido o art. do decreto citado no referido auto de infração. Pede, pois, respeitosamente que $V$. Exa, dignando-se atendê-lo, mande sindicar da suposta falta cometida e, ao menos pela equidade que tanto tem caracterizado a administração de $\mathrm{V}$. Exa, se digne ordenar a relevação da multa, aliás atenuado esse ato pelo seu estado de pobreza; visto que o Suplicante é um simples jornaleiro, sobrecarregado de numerosa família. ${ }^{37}$

Como podemos notar, Manoel usou algumas estratégias para tentar mostrar a Pereira Passos que não era justo que pagasse a multa imposta pelo agente. Inicialmente, buscou demonstrar "submissamente" que a acusação feita pelo fiscal municipal era apenas parcialmente verdadeira. De fato, ele fazia um acréscimo em sua propriedade, porém tal obra era de "Ionga data". Ou seja, se por um lado Manoel não negou que realizava melhorias em sua casa, por outro, procurou convencer o Prefeito de que esse acréscimo teve início antes do Decreto n. ${ }^{\circ} 391 \mathrm{e}$, portanto, não o havia infringido. Mas sua argumentação não parou por aí, pois, em seguida, pediu que fosse instaurada sindicância para verificar se houve mesmo infração. Desse modo, tinha como intuito dar credibilidade ao seu recurso, uma vez que colocava sua propriedade à disposição para averiguações.

Manoel solicitou também a "relevação" da multa por equidade, o que, em suas palavras, era uma atitude característica da administração de Pereira Passos. Realmente, diversos foram os casos em que o pedido de "relevação" de multa foi aceito, tendo como contrapartida o pagamento dos emolumentos. Para Manoel ter afirmado isso, é provável que circulasse entre a população a informação de que o Prefeito costumava deferir recursos por "equidade". Isso significa que era comum recorrer das multas recebidas, assim como socializar o despacho dado. Senão, como Manoel teria afirmado que a "relevação da multa por equidade" era uma característica da administração de Pereira Passos? Provavelmente, a quantidade de recursos por ele deferidos deve ter contribuído para essa imagem: entre 1903 e 1904, foram remetidos 40 recursos relacionados à construção no distrito de Inhaúma e desse total, 19 foram deferidos, sendo três por equidade.

Para finalizar o recurso, Manoel argumentou que o seu estado de pobreza servia de atenuante para a falta cometida, uma vez que era "um simples jornaleiro, sobrecarregado de numerosa família." Nas entrelinhas, o infrator julgava merecer o "perdão" da multa, porque não tinha condições de arcar com ela, em vista de sua situação econômica.

Ao chegar às mãos do agente, para que desse o seu parecer, Luiz Corimbaba reiterou sua opinião de que Manoel havia cometido a infração. Semelhante apreciação foi dada pelo engenheiro em 25 de maio de 1903. Com base nessas informações, três dias depois, Pereira Passos indeferiu o pedido do requerente. Apesar das estratégias adotadas por Manoel para livrar-se da multa, ele não obteve êxito. A seguir, acompanharemos um caso que teve início pelo mesmo motivo que esse, mas o desenrolar da história foi bem diferente.

Em 15 de maio de 1903, foi a vez de Antonio Jose Marques Pereira ser multado pelo agente Luiz Corimbaba, "por estar construindo paredes na casa de sua propriedade". ${ }^{38}$ De acordo com o auto de infração, ele descumpriu o art. $10^{\circ}$ do 
Decreto.$^{\circ} 391$ e, por isso, foi multado em 100\$000 (cem mil réis). O prazo para quitação da multa era até 20 de maio. Porém, em vez de pagá-la, Antonio escreveu ao prefeito:

Exmo Sr. Dr. Prefeito do Distrito Federal

O abaixo-assinado, morador do barracão à rua Tavares n. 6A, no Encantado, freguesia de Inhaúma, há dias multado por ter feito um pequeno puxado para uma cozinha, ignorando a proibição municipal, apela para V. Ex ${ }^{\mathrm{a}}$.

O requerente é muito pobre, tendo numerosa família; assim, na manifestação mais respeitosa, pede que $V$. Exa o releve desta pequena falta, devida unicamente ao desconhecimento da lei, ato a que sempre se sujeitou.

Confiado na magnitude do sentimento de V. Exa.

Pede favorável despacho. ${ }^{39}$

Com base na leitura do recurso, podemos perceber que o infrator utilizou dois argumentos para tentar evitar o pagamento da multa: inicialmente, afirmou que desconhecia a legislação acerca das construções e por isso cometeu a "pequena falta" de ter feito um "pequeno puxado para uma cozinha". Em outras palavras, não teria infringido a lei, se dela soubesse, inclusive, porque "sempre se sujeitou" às imposições legais. Com essa alegação, procurou construir uma imagem positiva a respeito de si mesmo perante o prefeito. Queria mostrar-se como um cidadão responsável, que cometera um deslize por ignorância. Ao mesmo tempo, Antonio justificou o pedido para que a multa fosse relevada devido à sua condição social: era pobre e tinha família numerosa, ou seja, seria difícil arcar com a despesa de $100 \$ 000$ (cem mil réis). Soma-se a esse fato a caracterização apresentada por ele acerca de sua habitação: um barraco. Como a Prefeitura poderia cobrar uma multa com aquele valor de um cidadão pobre e que fez melhorias em seu barraco, mas não obteve a licença por desconhecer a legislação sobre construções?

Apesar do recurso, o engenheiro da circunscrição afirmou que a multa foi bem aplicada, pois Antonio reconheceu sua infração. Portanto, a cobrança deveria ser mantida. O ajudante de $1 .{ }^{a}$ classe, Augusto C. Camisão de Mello ${ }^{40}$, por sua vez, deu o seguinte parecer:

Trata-se de um pequeno melhoramento feito em triste abrigo como tal nome merece um barracão de madeira, fechado, coberto de zinco, com 8 mo de área e a uma distância de 23 mo da rua, tendo 2 m10 de altura e que está servindo de habitação. O seu proprietário apenas aumentou-o de 9mo, conservando o mesmo pé direito, com paredes de tapume e argamassa de pura terra. Tal é a infração que a Agência com a maior solicitude procurou punir com um auto de multa quando junto dessa miserável choupana, no n. 4, em um prédio nobre, há um acréscimo que sem licença está sendo feito há um mês e que a despeito de ofício da digna Diretoria a Agência nenhuma providência se dignou tomar. ${ }^{41}$

Como é possível notar, temos aqui uma polêmica envolvendo os funcionários municipais, posicionando-se o ajudante de $1 .{ }^{a}$ classe a favor do infrator e o en-

39 Ibidem.

40 Segundo informações encontradas no Almanak administrativo, mercantil e industrial, Augusto C. Camisão de Mello consta como condutor de $1 .{ }^{a}$ classe. O cargo por ele ocupado fazia parte do quadro da Diretoria Geral de Obras e Viação. Cf.: SAUER, Arthur (org.). Almanak administrativo, mercantil e industrial do Rio de Janeiro para 1904. Rio de Janeiro: Companhia Tipográfica do Brasil, 1904, p. 501.

41 AGCRJ, Códice 10-1-9, Infração de posturas de Inhaúma (1903-1910). 
genheiro contra, ambos empregados da Diretoria Geral de Obras e Viação. Atentemos para as condições precárias de habitação em que vivia Antonio: seu barracão era feito de madeira, possuía $8 \mathrm{~m}^{2}$ de área e era coberto com "argamassa de pura terra". Nesse local, o pobre infrator residia com sua "numerosa" família. Embora tivesse mais do que dobrado a área construída, Antonio ainda vivia numa situação de penúria. Para tentar livrá-lo da multa, Camisão apontou para a injustiça cometida pela agência municipal, uma vez que próximo ao barracão de Antonio havia um "prédio nobre", que também fazia obras de acréscimo sem licença e seu proprietário não tinha sido multado.

Apesar do "contra-ataque" de Camisão, o engenheiro manteve-se firme em seu posicionamento: a multa deveria ser mantida, pois as obras estavam em desacordo com a lei. Outro parecer semelhante foi dado, mas não foi possível identificar sua autoria, nem o cargo de quem o emitiu. Certo é que, em 26 de maio, Pereira Passos deferiu por "equidade" o recurso de Antonio, que apenas ficou obrigado a pagar os emolumentos referentes ao acréscimo, calculados em 36\$000 (trinta e seis mil réis), valor bem menor do que o da multa inicialmente imposta. A dívida foi quitada em 13 de junho.

Esse caso é interessante pelas tensões que apresenta: a municipalidade, por intermédio de seu agente, aplicou uma multa elevada contra um indivíduo que vivia em condições precárias - em uma "choupana" que sequer ficava perto do alinhamento da rua Tavares. Porém, deixou de enquadrar nos mesmos critérios uma construção próxima e "nobre", diga-se de passagem. Cientes da injustiça praticada, tanto Antonio como o ajudante de $1 .^{a}$ classe lançaram mão dos recursos de que dispunham para negociar tal imposição. A Prefeitura, se não conseguiu receber pela multa, pelo menos fez com que Antonio cumprisse com a obrigação de pagar pelos acréscimos.

Ainda sobre as relações estabelecidas entre os funcionários municipais e os cidadãos que construíam nos subúrbios, vale a pena acompanhar a seguinte história. Em 20 de maio de 1904, Coriolano Goes, engenheiro responsável pelo distrito de Inhaúma, remeteu um memorando à Diretoria de Obras e Viação, solicitando a remoção do guarda que trabalhava em Bonsucesso, pois ele permitia "toda sorte de infrações" sem comunicar ao agente municipal, nem a ele, engenheiro. ${ }^{42}$ No documento, ele apresentou alguns exemplos da negligência do guarda: na rua Silva, três casas foram edificadas em desacordo com a lei; na casa n. 4 da rua 4 de Novembro foi feito "um puxado lateral ao prédio", assim como no n. 47 da estrada da Penha foi construído outro "puxado" nos fundos da propriedade.

Por causa da queixa dada pelo engenheiro, o agente Frederico Augusto Xavier de Brito, da agência de Inhaúma, foi instado a informar a respeito. Diante da solicitação, o agente percorreu as ruas de Bonsucesso, acompanhado de Coriolano, com o intuito de averiguar as infrações apontadas. Registrou toda a "sindicância" realizada e anexou-a em sua resposta ao diretor-geral de Polícia Administrativa, Arquivo e Estatística.

De acordo com tais documentos, na rua Silva, s/n. ${ }^{\circ}$, residia Guilherme Teixeira Bastos. Questionado sobre a casa de sapé que construíra, disse:

Que no dia quinze do corrente, principiou a construir dentro do terreno que arrendou em princípio do mês próximo passado, um rancho de sapé, para sua habitação e guarda de ferramentas empregadas na lavoura que tem no referido terreno.

42 AGCRJ, Códice 10-1-12, Infração de posturas de Inhaúma (1904). 
Que na segunda-feira - dezesseis do corrente, das oito para as nove horas da manhã, compareceu em sua casa o guarda Municipal Hermógenes, encarregado da secção que determinou ao depoente que parasse com as obras, visto não ter pedido licença e que dando-se por intimado compareceu na Agência do $19^{\circ}$. Distrito de Inhaúma, a fim de dar explicações.

Que o depoente agiu por seu motiv [ilegível] próprio e porque diversas pessoas lhe haviam garantido, que tratando-se de construção em zona rural, não havia necessidade de licença.

Que o guarda não sabia que o depoente pretendia fazer semelhante construção nem dele exigiu remuneração alguma. 43

A versão de Guilherme indica que ele não conhecia a legislação sobre construções, mas seus conhecidos sim, visto terem-lhe garantido que não era necessária licença para construir nos subúrbios. No final do documento, percebe-se a tentativa de isentar o guarda Hermógenes das irregularidades cometidas pelo infrator. Até aqui, não fica claro se essa iniciativa partiu do agente que levou a cabo a "sindicância" ou de Guilherme, ao perceber que o guarda seria punido.

Manoel do Rego Medeiros, residente no mesmo logradouro que Guilherme, porém na casa de $n .{ }^{\circ} 1$, também foi procurado pelo agente Frederico. Na ocasião, informou que sua habitação foi construída entre setembro e outubro de 1902, "época que não havia exigências de licença para construções no local que reside e é proprietário". Ao fazer tal declaração, demonstrou que tinha conhecimento do Decreto n. $^{\circ} 391$, assim como justificou a edificação de sua casa sem ter requerido a licença. Ainda de acordo com Manoel, nesse período, o guarda que ali trabalhava era o Sr. Hyppolito, "o qual à vista de não haver exigências, consentiu que o depoente construísse o prédio, não tendo portanto recebido remuneração alguma”. Nota-se, desse modo, que Manoel procurava mostrar que não havia cometido infração.

Para concluir suas explicações, afirmou que todas as construções da rua Silva eram anteriores à sua. Em outras palavras, nem ele, nem seus vizinhos tinham cometido qualquer irregularidade, tampouco o guarda responsável pela seção. Temos aí, portanto, mais uma tentativa de livrar o guarda Hermógenes das acusações feitas pelo engenheiro Coriolano.

Por fim, o agente Frederico procurou Alvaro Martins Teixeira para prestar esclarecimentos sobre a "construção do puxado em que reside". Morador à rua 4 de Novembro, "junto ao n 4 ", afirmou que o dito puxado fora feito em dezembro de 1902, inclusive, havia dado "coleta em 18 de Dezembro de 1903", ou seja, tinha pagado os devidos impostos referentes àquele ano. Estranhou que "depois de decorrido ano e meio seja intimado para dar explicações sobre uma construção feita em época que não havia lei que regulasse o assunto". Observamos aqui, mais uma vez, o mesmo argumento: Alvaro fez o seu "puxado" antes do Decreto n. 391. Inclusive, declarou que "Sr. Dr. Engenheiro suspeita ser nova [sua casa] apesar de ter passado por ela diversas vezes." Assim, procurava reforçar seu argumento e lançar dúvidas sobre o trabalho do engenheiro.

Com base em tais declarações, em $1 .^{\circ}$ de junho de 1904, o agente Frederico oficiou ao diretor-geral de Polícia Administrativa, Arquivo e Estatística. Em sua resposta, afirmou que, além de ter interrogado Guilherme, Manoel e Alvaro, colheu "informações de pessoas da circunvizinhança" a respeito das construções da rua Silva e 4 de Novembro. Elas disseram "que as referidas casas foram construídas há muito tempo". Ou seja, confirmavam o que havia sido dito pelos próprios "in-

43 Ibidem. 
fratores", assim entendidos apenas aos olhos de Coriolano, o engenheiro. Especificamente sobre a casa de sapé, o agente declarou que foi lavrado auto contra Guilherme, tão logo o guarda comunicou as irregularidades à agência de Inhaúma. Em seguida, concluiu:

Assim julgo que houve equívoco por parte do Sr. Dr. Engenheiro, que, encontrando as casas em questão, sem estarem rebocadas e emboçadas supôs tratar-se de construções novas, entretanto na referida localidade muitas outras casas estão nas mesmas condições.

[...]

O guarda em questão, tem até a presente data cumprido os seus deveres com escrúpulo, sendo de notar que na época em que se fizeram essas construções não era ele o guarda dessa seção. ${ }^{44}$

Ora, como podemos observar, o agente posicionou-se a favor do guarda, contrariando as acusações feitas pelo engenheiro da circunscrição. Além de ter apresentado provas para demonstrar que o guarda Hermógenes cumpriu com seus deveres, Frederico também construiu sua argumentação de maneira a comprovar essa tese. Para tal, Manoel e Alvaro apareceram como inocentes em relação às irregularidades de suas casas.

Após o recebimento do ofício do agente, solicitou-se que o engenheiro apresentasse a sua versão da história. Surpreso com o que afirmou Frederico, Coriolano escreveu longa resposta contrariando o que disse o agente. Para ele, a casa da rua 4 de Novembro, "junto ao n. 4" não era antiga, pois "o madeiramento empregado e exposto ao ar e luz, ainda não mudou de cor, não estava nem caiada, nem pintada, inclusive as portas e janelas". Embora Alvaro tenha afirmado que pagara o imposto referente a 1903, exibindo documento comprovando tal pagamento, Coriolano afirmou que verificou na Diretoria de Rendas e "a única casa sem número da referida rua pertence a Theophilo [ilegível] A. Barbosa e não a Alvaro Martins Teixeira" (ênfase no original).

Em relação à casa de . $^{\circ} 1$ da rua Silva, Coriolano declarou que quando realizava uma "excursão às estradas do Distrito", acompanhado pelos engenheiros Bezerra Cavalcanti e Rossi, perguntou à proprietária a respeito da licença, que os informou que não a possuía. Que sua habitação fora construída há uns seis meses, ou seja, no fim de 1903. "Essa afirmação foi confirmada por todas as pessoas a quem eu e o Sr. Agente nos disse [ilegível] pedindo informações. Entretanto, o Sr. Agente no documento n. 2 [referente a Manoel do Rego Medeiros] transporta a construção da dita casa para o ano de 1902!!!". ${ }^{45}$ Não foi apenas essa declaração do agente que deixou o engenheiro indignado. A respeito da casa de sapé, que ele encontrou em fase de construção durante as mesmas andanças pelo distrito, assim procedeu: "Ordenei imediatamente parar as obras e perguntei se o guarda tinha conhecimento das mesmas o que me foi dito negativamente!"

Vale lembrar que no documento que enviou inicialmente solicitando a remoção do guarda Hermógenes, Coriolano citou a falta de fiscalização em relação às casas da rua Silva, ao "puxado" da rua 4 de Novembro e a outro "puxado" na estrada da Penha, que não foi incluído na "sindicância". Segundo o engenheiro, esse último "puxado" foi construído em frente à casa do guarda. Diante de tais irregularidades, 
Me dirigi com o Sr. Agente à casa do guarda e as informações que tivemos é que as obras foram feitas sem licença com consentimento do guarda. Nesse ínterim, uma professora pública municipal cuja escola fica ao lado da casa da infratora pediu ao Sr. Agente que não multasse a proprietária e que nada fizesse ao guarda, o que de fato tem sido cumprido por parte daqueles.

Conclui-se portanto que o guarda, em vez de fiscalizar o que Ihe compete, deixa fazer obras clandestinas, todas contra a lei; que os documentos juntos não merecem fé, foram feitos ao sabor do guarda, mancomunado com os infratores e que os mesmos documentos contêm declarações descabidas e que muito previnem o espírito, como aqueles que se referem à remuneração do guarda pelos infratores, outras contraditórias, como o que existe no final do documento n. 2 "que todas as construções feitas na rua Silva são anteriores a do depoente (1902!), comparada com as que são feitas no documento n. 1 e finalmente inverídicas e adulteradas, apesar de ser invocado o meu testemunho, em virtude da fiel narração que faço e que estou pronto a provar com fatos e testemunhas de pessoas insuspeitas. ${ }^{46}$

Se as acusações de Coriolano fossem descabidas, provavelmente o agente Frederico não teria tido a preocupação de realizar uma "sindicância" para provar o contrário. Em nenhum dos livros de autos de infrações de posturas consultados encontrei procedimento semelhante por parte do agente do distrito. Além disso, do desenrolar dessa história, outras questões surgem: será que o engenheiro teria se equivocado em tantos casos, como quis provar o agente em sua sindicância? Por que justamente a infração da estrada da Penha, onde também residia o guarda, não foi verificada pelo agente?

Ora, todas essas perguntas nos levam a crer que as afirmações de Coriolano eram verídicas ou, pelo menos, factíveis. Sendo assim, tudo indica que existia um acordo entre aqueles que estavam sob a fiscalização do guarda, o próprio guarda e o agente de Inhaúma, para que os proprietários das construções feitas na região de Bonsucesso não pagassem licença. Com isso, ganhariam tanto os que construíam como os funcionários municipais envolvidos. Os primeiros porque não pagariam o valor da licença e os últimos porque, provavelmente, receberiam alguma recompensa em dinheiro.

Há que se observar também o fato de que a maioria dos infratores não gozava de boas condições financeiras, pois suas habitações eram precárias: alguns tinham construído "puxados" de madeira para residir, outro edificou uma casa de sapé. Ou seja, se recorreram a um acordo com o guarda ou com o agente do distrito, foi porque essa era uma das alternativas de que dispunham para diminuir as suas despesas. Aliás, essa estratégia era legítima, pelo menos, aos olhos dos envolvidos, pois até mesmo a professora primária sabia das irregularidades e pediu para que o engenheiro não punisse um dos infratores, nem o guarda. Se, por algum motivo, ela discordasse de tal prática, teria pedido a apuração das irregularidades e não o contrário. Vale destacar, inclusive, que o fato de Manoel do Rego Medeiros ter afirmado que todas as construções da rua Silva tinham sido feitas em 1902 ou anteriormente, também é indício da solidariedade entre aqueles habitantes, que procuraram, de diversas maneiras, esconder o acordo que existia entre eles.

Como a resposta de Coriolano está incompleta no livro de autos de infração consultado no Arquivo Geral da Cidade do Rio de Janeiro, resta acompanhar o último trecho disponível:

46 Ibidem. 
Lamento bastante que o Sr. Agente não fosse o primeiro a punir o guarda quando antes me havia dito que se admirava do seu procedimento, porquanto dera ordem ao guarda para que só viesse poucas vezes por semana à Agência a fim de melhor fiscalizar a sua seção. Longe disso fazer, corre a acobertá-lo com a sua proteção, empa[ilegível] as faltas arguidas e provadas contra o mesmo e ofendendo oficialmente e facilmente à minha dignidade, quando entre nós ambos tem havido, até a presente data, a mais completa harmonia de vistas na administração!

Espero entretanto que as providências necessárias hão de ser tomadas a bem das garantias das leis e da Repartição [... $]^{47}$

Provavelmente, trata-se do final do ofício. A partir de sua leitura, podemos concluir que para Coriolano, o agente do distrito de Inhaúma não procurou livrar o guarda Hermógenes das acusações, o que o deixou surpreso, pois até aquela data Frederico e ele tinham convivido em harmonia, mesmo ocupando cargos distintos. Na verdade, o que indignou Coriolano foi Frederico ter demonstrado um comportamento diante dele, mas ter apresentado relatório totalmente diferente ao diretor-geral de Polícia Administrativa, Arquivo e Estatística, inclusive, colocando em dúvida a sua palavra.

Em razão das versões contraditórias apresentadas pelos funcionários, recorreu-se à opinião do consultor técnico, Ernesto Silva. Segundo ele, os depoimentos dos donos das casinhas, utilizados por Coriolano e Frederico para argumentar sobre a questão, eram "imprestáveis para qualquer prova, visto partirem dos interessados diretos na questão". Diante disso, pareceu-Ihe conveniente, "a bem do serviço público e para evitar atritos", que o guarda Hermógenes fosse removido para outra seção até que os fatos fossem esclarecidos. Infelizmente, na documentação encontrada não consta o desfecho da história, que foi remetida ao Prefeito, mas cujo despacho não foi dado. De qualquer maneira, vale ressaltar que, mais uma vez, encontrei funcionários da agência municipal (um fiscal e um guarda) que se posicionaram ao lado da população e em contraposição ao engenheiro.

Em 26 de novembro de 1903, Joaquim Fernandes da Silva Maia foi autuado em razão de uma irregularidade cometida por seu inquilino. Em vez de realizar o pagamento da multa, escreveu o seguinte requerimento ao Prefeito:

Exmo. Sr. Dr. Prefeito

Joaquim Fernandes da Silva Maia tendo sido multado como infrator do art. 12 do Decr. no. 391 de 10 de Fevereiro do corrente ano, segundo a cópia do Auto junto, na importância de Rs200\$000 por ter construído sem licença uma cerca de tela de arame em frente ao seu terreno a Rua Goiás no. 138, vem respeitosamente recorrer para V. Excia. da imposição da referida multa.

O suplicante não foi quem construiu, nem quem mandou construir a referida cerca.

Segundo o doc. Junto, recibo da Agência do Distrito de Inhaúma, a licença foi requerida em 23 de Abril do corrente ano, pelo Sr. Antonio José da Silva, um pobre preto velho, inquilino do suplicante em aquele local.

Se não houve pagamento dos respectivos emolumentos, é porque, segundo lhe disse o próprio inquilino, na Agência Ihe disseram que não era preciso pagar licença para cercar o dito terreno, por tratar-se de uma substituição, visto como o dito terreno já era cercado com estacão e arame farpado, em muito mal estado.

47 Ibidem. 
O suplicante nenhum intuito tinha nem tem em prejudicar os Cofres Municipais. Por uma quantia relativamente pequena que lhe custaria a licença, não iria sujeitar-se aos incômodos de uma multa de $200 \$ 000$.

O suplicante está expondo os fatos, conforme chegaram a seu conhecimento. Não aumenta, nem diminui o que se passou.

Não é justo, porém, que o suplicante pague uma multa para cuja existência não concorreu.

Em última análise, se há emolumentos ou impostos a pagar a fim de legalizar a cerca do referido terreno, o suplicante quer pagá-los, como de direito e justiça.

Se assim for, o suplicante pede a V. Excia. que por espírito de equidade, se digne de deferir a presente petição, pagando o suplicante os impostos e emolumentos devidos.

Justiceiro, como o é, V. Excia há de fazer Justiça. ${ }^{48}$

Nota-se que o suplicante procurou justificar seu pedido de isenção da multa dando a entender que o agente fiscal agiu de má fé, pois informou o seu inquilino que não era necessário pagar emolumentos para cercar o seu terreno, porém, resolveu autuá-lo após a realização da obra. Utilizou-se ainda de duas estratégias: tentou demonstrar que não faria sentido deixar de pagar os emolumentos para depois ter que arcar com o valor de uma multa e se prontificou a quitar os impostos em troca da "relevação" da infração.

O agente, por sua vez, apresentou outra versão dos fatos: em abril de 1903, o inquilino Antonio José da Silva solicitou a licença para a construção da cerca, porém não quitou os emolumentos. Sendo assim, anexou ao processo uma cópia do pedido de licença com a informação de que os emolumentos somavam 35\$400 (trinta e cinco mil e quatrocentos réis). Afirmou ainda:

\footnotetext{
Embora não seja Antonio José da Silva o proprietário, me parece que em todo o caso, não teria requerido a licença sem que fosse autorizado pelo recorrente ou ao menos por este ouvido; tanto mais que sendo ele pobre como alega o recorrente não se achava em condições de arcar com as despesas.

É o que me cumpre informar no presente momento; o Sr. Dr. Prefeito resolverá como julgar de justiça. ${ }^{49}$
}

Os argumentos apresentados pelo agente eram plausíveis, especialmente por considerar o grau de pobreza do inquilino. Ao incluir uma cópia do pedido de licença no processo, buscou deixar claro que a justificativa de Joaquim era inconsistente, pois o valor dos emolumentos constava no documento. Mesmo assim, Pereira Passos optou por aceitar o pedido de Joaquim, solicitando apenas que pagasse os impostos devidos em $48 \mathrm{~h}$. Esse é mais um caso que evidencia as tensões entre os funcionários municipais e a população, bem como entre o prefeito e seus subordinados, pois o suplicante elaborou uma versão para evitar o pagamento da multa, que colocava em dúvida a atuação do agente e que foi acolhida pelo chefe do Executivo.

Em suma, as justificativas para solicitar a "relevação" das multas eram diversas. Alguns infratores afirmavam desconhecer a legislação, mas se dispunham a pagar os emolumentos necessários, cujos valores geralmente eram bem inferiores aos da autuação. Outros procuravam comprovar que tinham dado início à obra an-

48 AGCRJ, Códice 10-1-9, Infração de posturas de Inhaúma (1903-1910). Grifos no original. 49 Ibidem. 
tes da publicação de determinada postura ou decreto, dando a entender, portanto, que a autuação foi equivocada e que a legislação não era retroativa. Também havia aqueles que simplesmente alegavam ser muito pobres e que não tinham condições de pagar a multa. Outros, por sua vez, combinavam os argumentos acima e ainda apostavam no espírito "justiceiro" de Pereira Passos, ou na "equidade que tanto tem caracterizado a administração de V. Excia.".

Os conflitos decorrentes da observância das posturas municipais também transparecem nas circulares. Em 24 de agosto de 1903, por exemplo, foi publicada a Circular $n .{ }^{\circ} 80$, que revela as dificuldades em colocar em prática as determinações do Decreto n. ${ }^{\circ} 391$. Como muitos autos eram lavrados sem as devidas especificações, a municipalidade acabou por enfrentar problemas. Observemos:

\begin{abstract}
Sr. Agente da Prefeitura no distrito de... casos de infrações de obras em que há consertos em divergência com a licença, deveis declarar especificamente nos respectivos autos de multa no que consiste a divergência encontrada e não simplesmente, como fazeis, - que existem reparos, ou obras excedentes da licença, sem indicar entretanto quais sejam elas.

Como tal falta de declaração tem dado lugar a contínuas absolvições na Junta de Contravenções com grave prejuízo da Municipalidade, sereis mento das ordens que vos transmito.

O que levo ao vosso conhecimento para os devidos fins.

Saudações. - Aureliano Portugal..$^{50}$
\end{abstract}

Recomendo-vos, de ordem do Sr. Prefeito do Distrito Federal, que, nos doravante responsáveis por tal fato, se este resultar do não cumpri-

Como é possível notar, a intensificação do controle sobre as construções e o consequente aumento no número de autuações esbarrou na atuação da Junta de Contravenções, uma esfera do Poder Judiciário..$^{51}$ Diante disso, a Prefeitura lançou mão de duas medidas para minimizar os prejuízos: destacou a necessidade de preencher corretamente os autos de infração, assim como usou da coerção para obrigar os agentes fiscais a obedecer às recomendações da circular, caso contrário, seriam responsabilizados pelas absolvições na referida junta. Um mês após a publicação dessa circular, ela foi reiterada com os mesmos argumentos, pois ainda eram constantes a "insuficiência e irregularidade nas declarações e outros vícios de nulidade dos autos de infração lavrados nas agências da Prefeitura". ${ }^{22} \mathrm{~A}$ atuação do Poder Judiciário, portanto, é outro fator a ser considerado para entender a discrepância entre as multas aplicadas e pagas.

É importante levar em consideração também que o Decreto $n .^{\circ} 391$, colocado em vigor no início da administração de Pereira Passos, era bastante rigoroso em relação aos critérios que deveriam ser seguidos por aqueles que construíam ou reformavam suas moradias, sobretudo no que diz respeito à salubridade. A legis-

50 Circular.$^{\circ} 80$, de 24 de agosto de 1903.

51 De acordo com o Decreto n.o 4.769, de 9 de fevereiro de 1903, sancionado pelo presidente da República, pertencia à Junta de Contravenções o "processo e o julgamento das infrações de leis, posturas e regulamentos municipais". Ela deveria ser composta pelo juiz dos feitos da Fazenda Municipal e por dois pretores. Suas audiências deveriam ser realizadas duas vezes por semana. Findo o processo administrativo, após a verificação das infrações, o infrator era citado para se ver processar e julgar. Durante a audiência, era lido o auto de infração, o infrator era qualificado, as testemunhas de defesa e de acusação prestavam os seus depoimentos, se presentes, o procurador ou solicitador dos feitos da Fazenda Municipal produzia a sua acusação e o "infrator" ou o seu procurador proferia a defesa oral. Em seguida, o julgamento era realizado e proferido.

52 Circular n. ${ }^{89}$, de 26 de setembro de 1903. 
lação que predominou durante a década de 1890 não era tão escrupulosa. É plausível supor, portanto, que os próprios agentes tivessem dificuldades em garantir o fiel cumprimento do referido decreto e cometessem equívocos no preenchimento dos autos de infração, fato que o Prefeito tentou coibir por meio das punições supracitadas.

Por outro lado, a preocupação com a observância de tais preceitos sanitários e higiênicos, característica marcante da administração de Pereira Passos e dos debates travados à época em razão das reformas, também deve ser considerada para entender a intensificação da fiscalização por parte da municipalidade. Soma-se a esse aspecto a necessidade de angariar fundos para financiar as obras projetadas. A comparação entre os valores arrecadados com as multas por infração de posturas entre 1901 e 1903 evidencia essa política.

Ainda que a quantidade de infrações nos distritos suburbanos tenha sido pequena se comparada a da zona urbana, isso não quer dizer que a fiscalização naquela região tenha sido inexistente. A disparidade entre as multas aplicadas e pagas demonstra o quão intensa foi a atuação do poder público municipal nos subúrbios. Contudo, seus habitantes não aceitaram tacitamente esse controle. Sempre que possível, procuraram questionar as multas aplicadas e evitar o pagamento delas. Os argumentos utilizados para alcançar tal objetivo foram diversos. Entretanto, é importante destacar uma característica que unificava todos eles: os requerentes acreditavam na possibilidade de negociação com a municipalidade, caso contrário não entrariam com recurso. Os constantes deferimentos concedidos pelo Prefeito reforçavam essa crença. Durante 1903, foram 54 autuações referentes à falta de licença para construção ou por irregularidades em obras, em Inhaúma. Desse total, pelo menos 12 infratores entraram com recurso para não pagá-las, o que corresponde a $22 \%$ dos autuados, e apenas quatro tiveram os seus pedidos negados. Portanto, embora tenha ocorrido uma intensificação do controle sobre a população — e até mesmo sobre os funcionários municipais — para garantir a observância da legislação municipal, tal política foi frequentemente contestada, resultando, pelo menos nos subúrbios, na nulidade de diversas multas aplicadas.

Como bem afirmou Benchimol, o ônus das reformas recaiu sobre a população. O aumento no número de autuações é uma evidência disso. Entretanto, ao investigar o modo como os trabalhadores suburbanos lidaram com as multas que lhes foram impostas, é possível perceber que muitos deles vislumbraram a negociação com o poder público como uma alternativa possível, para não dizer necessária em diversos casos. Para muitos desses trabalhadores, que gozavam de condições precárias de habitação, a contestação das autuações era uma forma de minimizar as dificuldades que enfrentavam, sobretudo em termos econômicos.

Sob influência dos estudos recentes a respeito das Câmaras Municipais como espaços de demanda e disputa, procurei explorar um outro aspecto da experiência dos trabalhadores no âmbito da cidade, ao investigar as relações estabelecidas entre esses sujeitos históricos, os funcionários municipais e o chefe do Executivo. Duas características importantes dessas relações podem ser apontadas. Uma delas diz respeito aos usos políticos da legislação vigente. Vários requerentes conheciam os meandros das posturas em vigor e construíam os seus argumentos procurando brechas que pudessem livrá-los das autuações. Longe de serem vítimas indefesas do amplo processo de reestruturação urbana em curso na capital federal, forjaram maneiras, no âmbito da legalidade, para diminuir o seu impacto.

A configuração de laços de solidariedade entre os indivíduos que vivenciaram essa intensificação da fiscalização por parte da municipalidade carioca é outra 
característica a ser considerada. Curiosamente, não foram raros os casos em que os funcionários tomaram partido daqueles que deveriam ser autuados, demonstrando a complexidade de tais relações. Para compreender esse aspecto, é importante levar em consideração as divergências na interpretação da legislação, as disputas entre os próprios funcionários, assim como a insatisfação de muitos deles com a pressão exercida pelo Prefeito para que cumprissem as suas funções. A recorrência de circulares publicadas com orientações sobre como eles deveriam proceder, sobretudo os agentes fiscais, dá indícios das tensões que permeavam essas esferas de poder. A própria atuação de Pereira Passos tornava as relações entre habitantes e funcionários mais problemática, pois, ao mesmo tempo que exigia rigor no cumprimento da legislação, desautorizava agentes e engenheiros diante dos infratores, perdoando a multa de indivíduos que claramente tinham cometido a infração.

Por fim, vale destacar que o deslocamento do eixo de análise dos distritos diretamente atingidos pelas obras de renovação urbana para a zona suburbana está relacionado à necessidade de matizar esse processo. A historiografia que abordou o período do "bota-abaixo" durante a década de 1980 se dedicou ao estudo das principais mudanças que ocorreram nos distritos centrais e portuários e na legislação em vigor, destacando o papel do Estado nesse processo e identificando os grupos sociais beneficiados e prejudicados. Entretanto, ao se concretizarem não apenas pela realização de obras de grande vulto e na revitalização do porto, mas também pela intensificação dos mecanismos de fiscalização de seus habitantes, elas atingiram a cidade como um todo, porém com intensidades diferentes. A investigação da experiência dos trabalhadores suburbanos diante desse processo é uma alternativa para complexificar o entendimento a respeito dos impactos de tais reformas.

Recebido em 23/04/2013

Aprovado em 05/05/2013 